\title{
THE RELATIONSHIP BETWEEN HUMAN INTELECTUAL CAPITAL AND INNOVATION CAPACITY IN THE PUBLIC SECTOR
}

\author{
Rodrigo Belmonte da Silva \\ Management and Business Axis \\ Federal Institute Farroupilha \\ São Vicente do Sul, Rio Grande do Sul, \\ Brazilrodrigo.silva@iffarroupilha.edu.br
}

\author{
Carlos Maria Fernandez Jardón \\ Department of Applied Economics \\ University of Vigo, Vigo, Spain \\ IDLAB, National Research University Higher School of \\ Economics Perm, Russian Federation \\ cjardon@uvigo.es
}

\author{
Reception date: 12/16/2020 - Approval date: 01/20/2021 \\ DOI: https://doi.org/10.36995/j.visiondefuturo.2021.25.02R.004.en
}

\section{ABSTRACT}

The public sector must respond to the citizens' demands with speed and innovation. This ability can prevent many deaths, as in the case with the Covid-19 pandemic. The present study has the general objective of identifying the influence of human intellectual capital on the public sector capacity to innovate. To this end, 158 public servants, who occupy leadership positions in the municipal public administration of the city of Latin America (Santiago - Rio Grande do Sul - Brazil), were interviewed. The statistical technique used was exploratory factor analysis and, through the analysis of the main components, two human capital factors were extracted: training and skills, values and attitudes, in addition to the constructs of innovation capacity: services and processes, organizational and institutional. The study tested the hypothesis that all human capital factors are positively, significantly and directly related to the dimensions of innovation capacity. The most relevant index of correlation was identified among the variables: values and attitudes, and the capacity of services and processes. Therefore, the case of study verified the positive, direct and significant influence of human intellectual capital with the public sector capacity to innovate, specifically, in the local / municipal public administration in question.

KEY WORDS: Intellectual capital in the public sector; Human capital; the Public sector capacity to innovate; Innovation in the public sector; Knowledge management.

\section{INTRODUCTION}

The knowledge management has the potential to influence, improve processes and renew the public service, in addition to being an important enabler to maintain efficiency in all areas (Massaro, Dumay \& Garletti, 2015). In this context, local/municipal public administrations face an environment with complex problems (Demircioglu \& Audretsch, 2018), such as: social inequalities, violence, population aging, major epidemics, such as the

\footnotetext{
“Visión de Futuro" Año 18, Volumen No 25 N², Julio - Diciembre 2021 - Pág 137 - 153 URL de la Revista: http://visiondefuturo.fce.unam.edu.ar/index.php/visiondefuturo/index URL del Documento: https://visiondefuturo.fce.unam.edu.ar/index.php/visiondefuturo/issue/view/21 ISSN 1668 - 8708 - Versión en Línea E-mail: revistacientifica@fce.unam.edu.ar

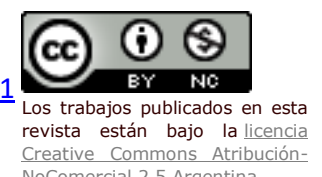


one currently experienced with the Covid-19. To solve them, the local governments must respond with innovations (Lewis et al., 2018).

Knowledge, from this approach, is distinguished as Intellectual Capital (Rodrigues et al., 2015) which, at present, is defined as an integrated dynamic of knowledge, experiences, intellectual property, organizational practices and information (Dumay, 2016) resulting of the intangibles assets to create values (Bratianu, 2018; lacuzzi et al., 2020). In the public sector, knowledge became a fundamental intangible asset, taking into account the combination of some of its elements which are studied and correlated with innovation (Demircioglu \& Audretsch, 2018; Lewis et al., 2018).

Human capital is one of the elements of knowledge, specifically of intellectual capital (Stewart, 1998). This dimension is defined as “(...) all the aspects that involve aptitudes and competences of public servants, since their knowledge and abilities are fundamental to the achievement of the objectives of an entity (Rossi et al., 2016, p.698)". Considering that the complex environment is part of the day - to - day life of the public sector and, in this sense, the ability to promote innovations is the premise for efficiency, quality and added value, the investigation of the correlation between this issues takes a relevant proportion.

However, the investigations in the private sector present consistent empirical results between human capital and innovation (Rodrigues et al., 2009; 2015; Jardón \& Martos, 2014; Costa, 2010), there are no similar records in the public sector.

Other studies addressed the knowledge in the public sector (Lewis et al., 2018; Demircioglu \& Audretsch, 2018) and identified intangible factors (leadership quality, innovation drives, communication levels) that positively impact on the capacity to innovate in the European municipal governments, such as: Barcelona, Copenhagen and Rotterdam. However, the influence of the human capital over theses, is unknown.

The existence of a theoretical gap should be explored: the influence of the elements of the human capital and its relationship with the capacity to innovate, specific to the public sector, taking into account the great differences between this sector and the private one (Koch et al., 2005). In addition to the relationship between factors, the proposal is expected to reveal specific, quantitative variables of human capital, expanding Rossi et al., (2016) findings, and the capacity to innovate items proposed by Lewis et al. (2018) and Demircioglu and Audretsch (2018).

From a practical point of view, the Covid-19 pandemic, for example, requires from the governments/local administration innovations and promptness in their practices and services (Entress et al., 2020; Leslie, 2020). Entress et al. (2020) assert that leadership in death care in the United States, for example, lacks a human centered approach. In this sense, public 
policies that promote equitable innovations and protect the interests of citizens seem to be premises at this time (Leslie, 2020). Then, the practical contribution of this article consists in pointing out human capital variables that favor innovative practices of leaders in local public administration, with the objective of accelerating the dynamic in the development of new/modified services and processes, new objectives and organizational methods and, in addition, the capacity of innovate in policies and institutional relationships.

Therefore, the main objective of the article seeks to answer the following key question: Does human intellectual capital influence the local public sector capacity to innovate? What components of the human capital influence the local public sector capacity to innovate? The study proposes to analyze the specific case of the city council of America Latina, which has a solid management model that has been in place for more than ten years.

To achieve this objective, the methodology was divided into two stages: in the first one, components and theoretical variables of human intellectual capital and the capacity to innovate were proposed. Next, dimensions and variables were tested, establishing correlations, testing the research hypotheses to finally, suggest ways to enhance the development of human capital as well as the capacity to innovate in the context under study.

The article starts with an introduction and continues with a brief theoretical review and a correlation between topics. The review is based on the formulation of research hypotheses to be tested according to the methods of analysis adopted. The data were tabulated and analyzed, oriented towards the answers of the hypotheses. Finally, practical and theoretical paths about the topics are recommended, in addition to pointing out the possibilities for future researches.

\section{DEVELOPMENT}

\section{Human intellectual capital and capacity to innovate in the public sector}

Human capital is defined by Ekemam and Okpara (2020) as the stock of skills, knowledge and attributes embodied by individuals in their ability to perform de job. In other words, it is the knowledge that staff members take with them when they leave the building, reflecting their wisdom: knowledge, skills, experiences (Duff, 2018) which influence innovation.

Hartley (2005) presents a peculiar argument in relation to the topic in the public sector. The author argues that this sphere considers innovation as novelty in action, that is, new ideas that work, in this case, it goes beyond an intention, it means an idea put into practice. This argument recognizes that putting the new into practice depends on changing, breaking

\footnotetext{
"Visión de Futuro" Año 18, Volumen N²5 N², Julio - Diciembre 2021 - Pág 137 - 153

URL de la Revista: http://visiondefuturo.fce.unam.edu.ar/index.php/visiondefuturo/index

URL del Documento: https://visiondefuturo.fce.unam.edu.ar/index.php/visiondefuturo/issue/view/21

ISSN 1668 - 8708 - Versión en Línea

E-mail: revistacientifica@fce.unam.edu.ar
} 
with the past, expressively affecting the way the organization operates, or going further: transforming its philosophy of existence. Moore et al., (1997, p.276) defend this postulate by stating that " $(\ldots)$ it is worth recognize these changes as innovation, (...) it must be something new to the organization, to be large, general and durable enough to significantly affect the operation or character of the organization".

Therefore, for the purposes of this paper, the most appropriate definition of innovation for the public sector is defined as the process of generating and implementing ideas, new and significantly modified, in order to creating value for society, whether they have an internal or external approach to public administration (European Commission, 2013).

Researchers recognize that there are factors referred to as determinants (Isidro-Filho, 2017), inducers (Halvorsen et al., 2005; Koch \& Hauknes, 2005; Agolla \& Lill, 2013) or drives (Lewis et al., 2018) which precede innovative outcomes, thus, identified as capacity to innovate.

The capacity to innovate is classified as one of the typologies of dynamic capabilities (Wang \& Ahmed, 2007). The context of dynamic capabilities is related to resource based theory (Penrose, 1959; Williamson, 1975; Teece, 1986; Wernerfelt, 1984), which argues that organization maintain a competitive advantage through their internal resources. To Teece et al. (1997), the dynamic capability is defined as the ability to renew the competences in order to align with changes in the business environment. The more critical the timing and the more complex the changes, the greater the need for certain innovative answers.

There are two theoretical approaches to thinking about dynamic capabilities (Meirelles \& Camargo, 2014), which are also made up by the capacity to innovate (Wang \& Ahmed, 2007). The first considers behaviors, skills and organization capabilities (Andreeva \& Chaika, 2006; Wang \& Ahmed, 2007), and the other one defends the capacity to innovate based on processes and routines (Zollo \& Winter, 2002; Winter; 2003; Dosi et al., 2008). Considering the specificities of the public administration in relation to the heterogeneity and complexity of its environment (Demircioglu \& Audretsch, 2018) demand distinguishable behaviors and skills. From this point of view, the definition based on the concepts of Meirelles \& Camargo (2014), Zollo \& Winter (2002), Teece et al. (2007), Wang \& Ahmed (2007); Lewis et al. (2018) \& Demircioglu \& Audretsch (2018), is mentioned:

\footnotetext{
"the ability/capability to develop new services, processes, organizational and institutional strategic changes, based on knowledge, skills, routines, processes and learning and governance mechanisms of the municipal/local public administration".
}

Some research evidences make the relationship between human capital and the capacity to innovate promising. Demircioglu y Audretsch (2018), for example, argue that the intangible assets, based on knowledge, are influential and determinant in the development of "Visión de Futuro" Año 18, Volumen $\mathbf{N}^{\circ} \mathbf{2 5}$ N $^{\mathbf{2}}$, Julio - Diciembre 2021 - Pág 137 - 153
URL de la Revista: http://visiondefuturo.fce.unam.edu.ar/index.php/visiondefuturo/index
URL del Documento: https://visiondefuturo.fce.unam.edu.ar/index.php/visiondefuturo/issue/view/21
ISSN 1668 - 8708 - Versión en Línea
E-mail: revistacientifica@fce.unam.edu.ar 
capabilities and complex innovation in the public sector. The results of their research suggest the employees' innovative behavior and cooperation, in addition to collaborating with important external sources and the capability to work in a complex environment, are positively associated to the innovation in the public sector, suggesting that influences of innovations comprise individual, organizational and relational levels.

On the other hand, Henttonen and Ritala (2016), using structural equation modeling of research data, asked 595 members of a public organization whether shearing individual level information (in terms of attitudes, estimation of benefits, self efficacy and actualized behavior) affected individual job performance. The results confirm the hypothesis that the intention to share knowledge impact individual and collective performance.

Recently Jalloh and Ming (2020) confirmed that people training, i.e., training and development, compromise and employee engagement serve as strategic elements that facilitate human capital development in organizations. Besides, they found out that appropriate distribution of financial and non-financial rewards are used as motivation and stimulate people to unleash their creativity and shrewdness for sustainable growth of organizations.

In this scenario, where the existence of a positive influence between human capital and capacity to innovate in the local public administration is considered, in this bias, the hypothesis to be tested are:

H1_Human Capital (HC) influences the capacity to innovate of services and processes

H.2_Human Capital $(\mathrm{HC})$ influence the capacity for organizational innovation.

H.3_Capital (HC) influence the capacity for institutional innovation.

\section{Methodology}

The hypothesis were tested in the Local/municipal public administration of Latin America city, specifically, in Brazil's southernmost state (Santiago - Rio Grande do Sul). In the city hall, managers of secretariats, departments and sectors were surveyed, among them, public servant who had compete and in temporary regime, taking into account that in Brazil there are other functional models.

Responses were collected between December 2019 and February 2020 using targeted and unidentified questionnaires. A total of 158 returns were received, representing a response rate of $87.7 \%$. All municipal secretariats answered the questions and presented a response rate over $75 \%$.

The research instrument was prepared based on theoretical and empirical studies about the following topics: human intellectual capital and innovation in the public sector, 
having been tested, in the first place, with a restricted number of servers to adjust a assess the questions, in addition to verifying their clarity and comprehension. The choice of research subjects considered the degree of strategic and tactical leadership, since they are directly involved in organizational management and public policies, supposedly well informed about these and, above all, about the management model of the city hall and, consequently, its strategic choices.

\section{Measurements}

The constructs were measured through a five points scale Likert questionnaire. The factors of intellectual capital and capacity to innovate were analyzed in a multidimensional way, and new scales were developed to this topics based on theoretical and empirical research used (Rossi et al., 2016; Santos-Rodrigues et al., 2015; Bueno et al., 2011, Jardón \& Martos, 2014, Demircioglu. \& Audretsch, 2018, Grčić \& Samaržija, 2016; Lewis et al., 2018, De Vries et al., 2016).

The dimension of human intellectual capital relevant to the capacity to innovate in the public sector were measured based on the organization of the following factors:

- Training and skills - as representation of a set of knowledge and skills needed to innovate (Bueno et al., 2011; Rossi et al., 2016).

- Values and attitudes - as personal values and attitudes necessary to innovation (Bueno et al., 2011, Rossi et al., 2016).

On the other hand, the constructs that shaped the capacity to innovate in the public sector are concentrated in three dimensions:

- Services and processes innovation capability - ability to create or modify way in which services and processes are designed or delivered to users (Hartley, 2005; Koch et al., 2005).

- Organizational innovation capacity - ability to create or modify contexts, goals, concept or purposes (Hartley, 2005; Koch et al., 2005; Halvorsen, 2005) or conceive/change organizational ways introducing new management techniques and/or rewards or new work methods (Bekkers et al., 2006).

- Institutional innovation capability - refers to fundamental transformations in institutional relationships between organizations, institutions and other public sector actors and, more specifically, in public administration (Bekkers et al., 2006).

\footnotetext{
"Visión de Futuro" Año 18, Volumen No 25 N², Julio - Diciembre 2021 - Pág 137 - 153

URL de la Revista: http://visiondefuturo.fce.unam.edu.ar/index.php/visiondefuturo/index

URL del Documento: https://visiondefuturo.fce.unam.edu.ar/index.php/visiondefuturo/issue/view/21

ISSN 1668 - 8708 - Versión en Línea

E-mail: revistacientifica@fce.unam.edu.ar
} 


\section{Statistical techniques}

The first step in relation to the data was to consider the temporary servers' responses, taking into account that the effective servers' answers present more reliable index in relation to the normalization of the data. Another aspect is that effective servers are less sensitive to changes in government, theoretically impartial, taking into account their functional stability. Thus, the sample was reduced to 104 validated surveys.

For the definition of the constructs of human intellectual capital and capacity to innovate, exploratory analysis using MCA (Main components analysis) was used. Variables with scores below to 0,4 were not taking into account due they were not similar to the rest of the items. The factors were reduced to better explain the information collected, for this, the Kaiser method with a percentage higher than $50 \%$ clarifies the total variance.

Rotation was used in the items of human capital with the intention of adjusting the original to the different axes and organize them into appropriate factors. The validation of this technique was achieved using Bartlett's test and Kaiser-Meyer and Okin coefficient (KMO). Cronbach's Alpha coefficient tested and verified the internal consistency of the questionnaire, considering indexes above 0,6 as adequate (Hair Jr., et al, 2005).

To finally verify the hypotheses that motivated this study, linear regression techniques were used to evaluate and compare the direct effect of each independent variable on the dependent variable. The process of data analysis and treatment, as well as the evaluation of the data, was carried out using a statistical package for the social sciences (IBM SPSS Statistics - version 22 in Portuguese).

\section{Empirical results}

The empirical analysis was carried out in two stages: first, the reliability of data and the exploratory factorial analysis were investigated, to then analyze the correlation between the variables which make up the human capital and the capacity to innovate and answer the proposed hypotheses.

\section{Reliability}

Cronbach's Alpha coefficients present indexes above 0,8, indicating a high reliability and consistency of internal data (Hair Jr. et al., 2005), as show in table 1. The same authors stat that an acceptable level of reliability (above 0,7 ) means that the respondents answered the questions consistently.

Table 1 - Reliability analysis - Cronbach's Alpha

\footnotetext{
"Visión de Futuro" Año 18, Volumen N²5 N², Julio - Diciembre 2021 - Pág 137 - 153

URL de la Revista: http://visiondefuturo.fce.unam.edu.ar/index.php/visiondefuturo/index

URL del Documento: https://visiondefuturo.fce.unam.edu.ar/index.php/visiondefuturo/issue/view/21

ISSN 1668 - 8708 - Versión en Línea

E-mail: revistacientifica@fce.unam.edu.ar
} 


\begin{tabular}{lcc}
\hline \multicolumn{1}{c}{ Constructs } & Items & Cronbach's Alpha \\
\hline Human Capital $(\mathrm{HC})$ & 18 &, 862 \\
Capacity to innovate $(\mathrm{Cl})$ & 8 &, 934 \\
\hline
\end{tabular}

Source: own production

\section{Exploratory factor analysis}

The technique proposes synthesize the information of a considerable number of variables in a smaller number of factors. For this purpose, a Main Components Analysis (MCA) was carried out in order to relate variables without determining to what extent the results are consistent with the proposed model (Rodrigues et al., 2009).

The criterion used for the statistical application was a CUT-off for 0,30 and that the factors explain at least $50 \%$ the proposed items. Next, the factors were distributed using a Varimax rotation with Kaiser Normalization, obtaining the constructs and their respective variables.

\section{Human intellectual capital}

The reduction of the data in all the human capital items presented a KMO index (Kaiser-Mayer-Olkin) that suggests a good correlation among the variables (KMO =0,831). On the other hand, Bartlett's test of sphericity indicated a significance level of 0,000 which distance the hypotheses that the correlation matrix is the identity matrix $(p<0,01)$. Therefore, the conclusion is that there is a correlation among the variables. With the statistical endorsement of the reliability of the data, it was possible to advance and confirm the specific results of the main components analysis, with 11 items distributed in 2 common factors and an explained variance of $54,67 \%$ (table 2). The distribution achieved a convergence of 3 interactions, according to the Vairmax rotation with Kaiser Normalization.

\footnotetext{
"Visión de Futuro" Año 18, Volumen No 25 No 2, Julio - Diciembre 2021 - Pág 137 - 153

URL de la Revista: http://visiondefuturo.fce.unam.edu.ar/index.php/visiondefuturo/index

URL del Documento: https://visiondefuturo.fce.unam.edu.ar/index.php/visiondefuturo/issue/view/21

ISSN 1668 - 8708 - Versión en Línea

E-mail: revistacientifica@fce.unam.edu.ar
} 
Table 2 - Components of Human Intellectual Capital

\begin{tabular}{|c|c|c|}
\hline Component & Item & $\begin{array}{l}\text { Component } \\
\text { Rotation } \\
\text { Varimax }\end{array}$ \\
\hline \multirow{7}{*}{$\begin{array}{l}\text { (Training and } \\
\text { skills) }\end{array}$} & $\begin{array}{l}\text { I have a high capacity for communication and I intend to } \\
\text { share my knowledge. }\end{array}$ & ,746 \\
\hline & $\begin{array}{l}\text { I consider myself as highly qualified and talented, to the } \\
\text { point of increasing my responsibilities. }\end{array}$ & ,717 \\
\hline & $\begin{array}{l}\text { I have specialized knowledge in specific areas, } \\
\text { guaranteeing superior performance. }\end{array}$ & ,716 \\
\hline & I am generally self-motivated for work. & ,678 \\
\hline & $\begin{array}{l}\text { I contribute effectively in the search for creative solutions } \\
\text { and new ways to solve problems. }\end{array}$ & ,668 \\
\hline & $\begin{array}{l}\text { My educational background is compatible with the tasks } \\
\text { or functions that I perform. }\end{array}$ & ,638 \\
\hline & $\begin{array}{l}\text { My performance, in team work, generally shows better } \\
\text { results than the individual work. }\end{array}$ &, 515 \\
\hline & $\begin{array}{l}\text { I feel the clear desire to serve the public and I am } \\
\text { pleased to belong to the municipal servant staff. }\end{array}$ & ,847 \\
\hline CH2_Val_Ati & $\begin{array}{l}\text { I contribute effectively to the collective work and } \\
\text { cooperate whenever I asked to do so. }\end{array}$ & ,805 \\
\hline \multirow[t]{2}{*}{$\begin{array}{l}\text { (Values and } \\
\text { attitudes) }\end{array}$} & $\begin{array}{l}\text { I consider that the training, when offered (courses or } \\
\text { seminars), resulted in new knowledge to the function I } \\
\text { perform. }\end{array}$ & ,693 \\
\hline & $\begin{array}{l}\text { I consider myself as cordial and sociable when dealing } \\
\text { with public. }\end{array}$ & ,602 \\
\hline
\end{tabular}

Source: own production

\section{Capacity to innovate in the public sector}

The result of the MCA, with the same criteria applied to the elements of human intellectual capital, showed a KMO (Kaiser-Meyer-Olkin) index with a very good correlation among variables $(\mathrm{KMO}=0,835)$. Bartlett's sphericity showed a significance of 0,000 which

\footnotetext{
“Visión de Futuro" Año 18, Volumen No 25 N², Julio - Diciembre 2021 - Pág 137 - 153

URL de la Revista: http://visiondefuturo.fce.unam.edu.ar/index.php/visiondefuturo/index

URL del Documento: https://visiondefuturo.fce.unam.edu.ar/index.php/visiondefuturo/issue/view/21

ISSN 1668 - 8708 - Versión en Línea

E-mail: revistacientifica@fce.unam.edu.ar
} 
rejects the hypotheses that is the identity matrix $(p<0,01)$. Therefore, the conclusion is that there is a correlation among the element variables. Considering that the previous results confirm the statistical reliability, the description of the results of the extracted factors was advanced. These presented four items, explained by a variance of $77 \%$ (table 3 ). The distribution did not obtain a convergence due the fact that there is a single component.

Table 3 - Components of services and processes innovation capability

\begin{tabular}{ccc}
\hline Component & Item & $\begin{array}{c}\text { Components } \\
\text { matrix }\end{array}$ \\
\hline & New/modified internal services &, 883 \\
Cl_Serv.Proc & New/modified external services &, 879 \\
(Services y Processes) & New/modified internal work methods &, 903 \\
& New/modified ways to solve external tasks &, 845 \\
\hline
\end{tabular}

\section{Capacity for organizational innovation}

When analyzing these items, the PCA, using the same criteria as above, found a KMO (Kaiser-Meyer-Olkin) index suggesting an acceptable correlation among the variables $(\mathrm{KMO}=0,500)$. The Bartlett's sphericity demonstrated a significance level of 0,000 which rejects the hypotheses that the correlation matrix is the identity matrix $(p<0,01)$, proving the existence of a correlation among the items. Noting that the above data point to a statistical reliability, progress was made in the description of the results of the extracted factors, explained by a variance of $81 \%$ (table 4 ).

Table 4 - Components of organizational innovation capacity

\begin{tabular}{ccc}
\hline Component & Item & $\begin{array}{c}\text { Components } \\
\text { matrix }\end{array}$ \\
\hline Cl_Org & New/modified strategic objectives &, 765 \\
(Organizational) & New/modified server inventive methods &, 963
\end{tabular}

Source: own production

\footnotetext{
"Visión de Futuro" Año 18, Volumen No 25 No 2, Julio - Diciembre 2021 - Pág 137 - 153

URL de la Revista: http://visiondefuturo.fce.unam.edu.ar/index.php/visiondefuturo/index

URL del Documento: https://visiondefuturo.fce.unam.edu.ar/index.php/visiondefuturo/issue/view/21

ISSN 1668 - 8708 - Versión en Línea

E-mail: revistacientifica@fce.unam.edu.ar
} 


\section{Capacity for institutional innovation}

The MCA of the variable, using the same criteria as above, it was found a KMO (Kaiser-Meyer-Olkin) index suggesting an acceptable correlation among the variables $(\mathrm{KMO}=0,500)$. Bartlett's sphericity showed a significance level of 0,000 which rejects the hypotheses that the correlation matrix is the identity matrix $(p<0,01)$. Therefore, there is a correlation between the two items of the element. The results of the extracted factors showed two items, explained by a variance of $89,71 \%$ (table 5 ).

Table 5 - Components of institutional innovation capacity

\begin{tabular}{ccc}
\hline Component & Item & $\begin{array}{c}\text { Components } \\
\text { matrix }\end{array}$ \\
\hline $\begin{array}{c}\text { Cl_Inst } \\
(\text { Institutional })\end{array}$ & $\mathrm{Cl} .7-$ New/modified public policies &, 948 \\
& $\mathrm{Cl} .8-$ New/modified institutional relationships &, 946 \\
\hline
\end{tabular}

Source: own production

\section{Correlations}

To study the relationships between human intellectual capital and the capacity to innovate, regression between the variables of human capital with the proposed factors of the capacity to innovate in the public sector were carried out. B's with values above 0,200 were selected. In this way, it was possible to demonstrate the existence of strong relationships between the constructs and the capacity to innovate, as shown in tables 6, 7 and 8 .

Table 6 - Regression matrix: Human Capital and capacity to innovate of services and processes

\begin{tabular}{|c|c|c|c|c|c|}
\hline \multirow{3}{*}{ Model } & & \multicolumn{2}{|c|}{ Non-standardized coefficients } & \multirow[b]{3}{*}{$t$} & \multirow[b]{3}{*}{ Sig. } \\
\hline & & & Standard & & \\
\hline & & B & deviation & & \\
\hline \multirow[t]{2}{*}{1} & CH1_For_Hab & ,225 & ,082 & 2,730 & ,007 \\
\hline & CH2_Val_Ati & ,522 & ,082 & 6,333 & ,000 \\
\hline
\end{tabular}

Source: own production

The results indicate that the human capital is positively, directly and significantly related to the capacity to innovate of services and processes. The resulting model is:

$$
\text { Cl_Serv_Proces }=0,225^{*} \text { CH1_For_Hab }+0,522^{*} \text { CH2_Val_Ati }+\varepsilon \text {, }
$$

\section{Where:}

Cl_Serv_Proces $=$ Capacity to innovate of services and processes

CH1_For_Hab $=$ Human capital 1 - Training and skills

CH2_Val_Ati = Human Capital 2 - Values and attitudes

$\varepsilon,=$ Error

\footnotetext{
"Visión de Futuro" Año 18, Volumen No 25 N², Julio - Diciembre 2021 - Pág 137 - 153

URL de la Revista: http://visiondefuturo.fce.unam.edu.ar/index.php/visiondefuturo/index

URL del Documento: https://visiondefuturo.fce.unam.edu.ar/index.php/visiondefuturo/issue/view/21

ISSN 1668 - 8708 - Versión en Línea

E-mail: revistacientifica@fce.unam.edu.ar
} 
Furthermore, it is possible to conclude that Training and Skills $(0,225$ sig. 007) and Values and Attitudes (0,522 sig. 000) are variables of the human capital with significant, positive and direct effects on the capacity to innovate of services and processes.

Table 7 - Regression matrix: Human capital and organizational innovation capacity

\begin{tabular}{|c|c|c|c|c|c|}
\hline \multirow[b]{2}{*}{ Model } & & \multicolumn{2}{|c|}{ Non-standardized coefficients } & \multirow[b]{2}{*}{$\mathbf{t}$} & \multirow[b]{2}{*}{ Sig. } \\
\hline & & B & $\begin{array}{l}\text { Standard } \\
\text { deviation }\end{array}$ & & \\
\hline \multirow[t]{2}{*}{1} & CH1_For_Hab & ,231 & ,088 & 2,616 & 010 \\
\hline & CH2_Val_Ati & ,415 & ,088 & 4,712 &, 000 \\
\hline
\end{tabular}

Source: own production

The results indicate that human capital is positively, directly and significantly related to the organizational innovation capacity. The resulting model is:

$$
\text { Cl_Org }=0,231^{*} \text { CH1_For_Hab }+0,415^{*} \text { CH2_Val_Ati }+\varepsilon \text {, }
$$

Where:

Cl_Org = Organizational innovation capacity

CH1_For_Hab $=$ Human capital 1 - Training and skills

CH2_Val_Ati $=$ Human Capital 2 - Values and attitudes

$\varepsilon$, , Deviation.

The indices clarify that Training and Skills (0,231 sig. 010) and Values and Attitudes $(0,415$ sig. 000$)$ are variables of the human capital with significant, direct and positive effects on the organizational innovation capacity.

Table 8 - Regression matrix: Human capital and institutional innovation capacity

\begin{tabular}{cccccc}
\hline & & \multicolumn{2}{c}{ Non-standardized coefficients } & \\
\cline { 3 - 5 } Model & & B & $\begin{array}{c}\text { Standard } \\
\text { deviation }\end{array}$ & t & Sig. \\
\hline \multirow{2}{*}{1} & CH1_For_Hab &, 284 &, 082 & 3,475 &, 001 \\
& CH2_Val_Ati &, 496 &, 082 & 6,062 &, 000 \\
\hline & & \multicolumn{3}{c}{ Source: own production }
\end{tabular}

The results indicate that human capital is positively, directly and significantly related to the institutional innovation capacity. The resulting model is:

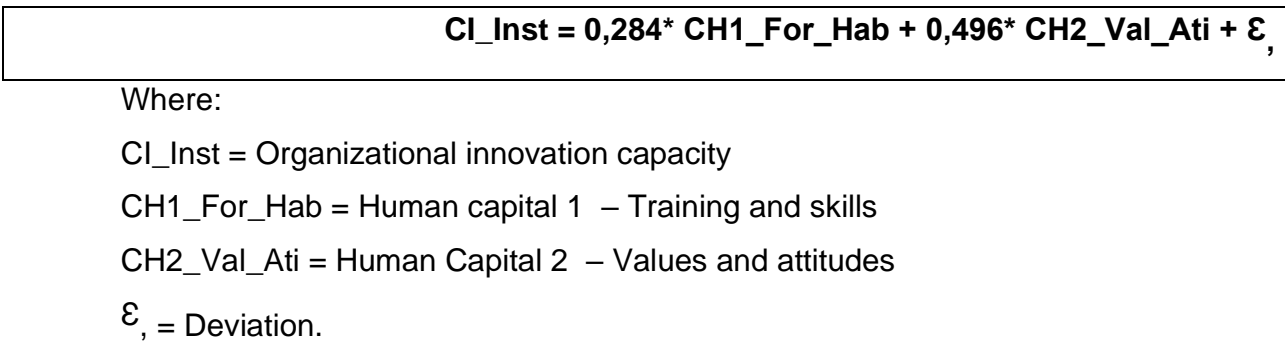


The indexes clarify that Training and Skills (0,284 sig.001) and Values and Attitudes $(0,496$ sig.000) are variables of the human capital with significant, direct and positive effects on the institutional innovation capacity. The final conclusions are shown in figure 1.

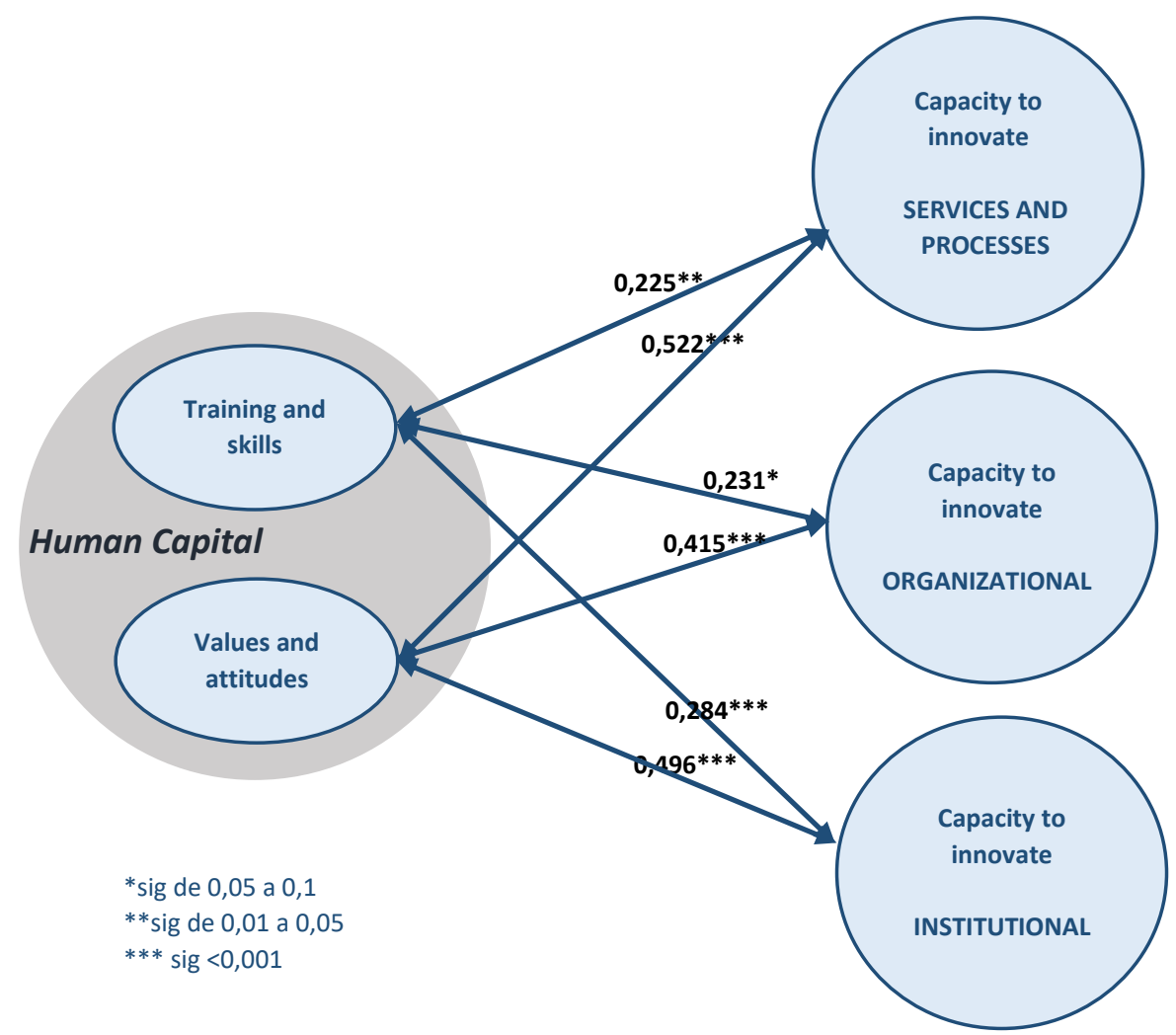

Figure 1 - Relationship between Human Intellectual Capital and Capacity to innovate in the public sector.

Source: own production

It can be concluded that the human intellectual capital has a positive, significant and direct influence on the capacity to innovate in the public sector, within the investigated context, as shown in table 9. All hypotheses are confirmed.

\footnotetext{
"Visión de Futuro" Año 18, Volumen No 25 No 2, Julio - Diciembre 2021 - Pág 137 - 153 URL de la Revista: http://visiondefuturo.fce.unam.edu.ar/index.php/visiondefuturo/index

URL del Documento: https://visiondefuturo.fce.unam.edu.ar/index.php/visiondefuturo/issue/view/21 ISSN 1668 - 8708 - Versión en Línea 
Table 9 - Test of Hypotheses

\begin{tabular}{cc}
\hline Hypothesis & Situation \\
\hline $\begin{array}{c}\text { H1. The Human Capital (HC) influences the capacity to innovate } \\
\text { of services and processes }\end{array}$ & CONFIRMED \\
& Positive \\
& Significant \\
& Direct \\
\hline H.2 The Human Capital $(\mathrm{HC})$ influences the organizational & CONFIRMED \\
innovation capacity & Positive \\
& Significant \\
H.3 The Human Capital (HC) influences the institutional & Direct \\
innovation capacity & CONFIRMED \\
& Positive \\
& Significant \\
& Direct \\
\hline
\end{tabular}

Source: own production

\section{H1. Human Capital (HC) influences the capacity to innovate of services and processes}

Hypotheses 1 was confirmed and both factors were demonstrated: Training and skills (CH1_For_Hab) and Values and Attitudes ( $\mathrm{CH} 2$ _Val_Ati) are associated to the capacity to innovation in services and processes in the public sector under study. Specifically, in relation to training (formal education) the findings of Pasamar et al. (2019) base their studies on the assumption that the formal education of individuals is directly proportional to the level of human development and individual performance. In this context, their findings point to human capital as a mediator between leaderships and learning, functioning as a strong link between them. Furthermore, they mention that: "individuals more open to new experiences and risks have shown that contribute more with development of radical ideas and have features such as motivation, educative profile, professional background and skills that can influence in the generation and implementation of ideas that lead to innovation" (Pasamar et al, 2019. p.30).

The confirmation of the hypothesis contribute with the proposal of the factor Training and Skills, as it bring together two aspects that have been widely explored in the context of human capital in the private sector. Putting the two issues together, the resulting argument of the factor argues that schooling, i.e., explicit knowledge in the public sector needs to be complemented by skills acquired though experience in the civil service, taking into account the constitutional legality demanded in public administration. Then, Training and Skills are defined as: formal knowledge and know-how to the efficient execution of civil service.

On the other hand, in the same way, Values and Attitudes factor demonstrated specificity when is related to the public sector, taking into account the public administration "Visión de Futuro" Año 18, Volumen $N^{\circ} 25$ N 2, Julio - Diciembre 2021 - Pág 137 - 153 URL de la Revista: http://visiondefuturo.fce.unam.edu.ar/index.php/visiondefuturo/index URL del Documento: https://visiondefuturo.fce.unam.edu.ar/index.php/visiondefuturo/issue/view/21 ISSN 1668 - 8708 - Versión en Línea 
principles in relation to morality, impersonality, publicity and efficiency required from servant, as well as self-initiative, full understanding and willingness in the execution of public function. Therefore, Values and Attitudes factor is defined as: convictions, conducts and behaviors that are legally and morally appropriated to the execution of public function.

\section{H.2 Human Capital (HC) influences the capacity for organizational innovation}

Hypothesis 2, in the same way, was confirmed; i.e., Training and Skills (CH1_For_Hab) and Values and Attitudes ( $\mathrm{CH} 2$ _Val_Ati) are associated to the organizational innovation capacity in the public sector under study. Nonaka and Takeuchi (2008) assert that schooling, specific knowledge, know-how skills will only be translated into innovative capacity when they are transformed into organizational knowledge. This statement seems to clarify the correlation between Training and Skills factor and the organizational innovation capacity. It will be human capital resulting from collective knowledge and transforming itself into new concepts, new organizational techniques or new working methods (Hartley, 2005; Koch et al., 2005; Halvorsen, 2005; Beckkers et al., 2006).

The major contribution in the organization of this hypothesis is found in the configuration of the organizational innovation capacity factor. While the private sector comprises the innovation drives present in the aforementioned capability, such as leadership, culture, routines and processes (Lewis et al., 2018), two fundamental aspects are pointed out from the point of view of this work to accelerate the innovation process and stimulate collectively the servants: new and/or modified strategic objectives and their guidelines with incentives to the servants. This methodological approach was confirmed with a positive relationship with human capital factors, shaping the need for alignment between strategy and incentives in the case under study.

\section{H.3 Human Capital (HC) influences the capacity for institutional innovation}

Hypothesis 3 also was confirmed. This means to asset that Training and Skills (CH1_For_Hab) and Values and Attitudes ( $\mathrm{CH} 2$ _Val_Ati) factors are associated to institutional innovation capacity. These results indicate that servant leaders demonstrate a high rate of job satisfaction and a kind of pride and, consequently, commitment with municipal public service. Commitment and motivation to serve are instruments that ensure effective performance in the organization and, as consequence, are directly related to the creation of an innovative products and processes environment (Easa y Orra, 2019; Ekemam y Okpara, 2020). These issues stimulate a favorable working climate for local management

\footnotetext{
"Visión de Futuro" Año 18, Volumen No 25 N², Julio - Diciembre 2021 - Pág 137 - 153 URL de la Revista: http://visiondefuturo.fce.unam.edu.ar/index.php/visiondefuturo/index

URL del Documento: https://visiondefuturo.fce.unam.edu.ar/index.php/visiondefuturo/issue/view/21 
to provide support for the formation of internal committees, an important creative asset capable to promote participatory management and creating/modifying services, processes and local public policies for the improvement of citizens' quality of life.

The configuration of the institutional innovation capacity factor was a new methodological theoretical contribution, compared to another researches in the public sector, taking into account that no other dimension with this name was identified, despite the existence of the institutional innovation dimension (Beckkers et al., 2006). The positive correlation with the human capital dimensions constitute a finding to stimulate innovation in the public sector, thus the interaction between managers and research bodies, universities, political power, community in general, besides allowing innovation in services and processes, also is a real possibility for creating innovation in public policies.

\section{CONCLUSIONS}

In summary, the study confirms the central question of the research: assets human capital influences (positively, significantly and directly) the capacity to innovate (services and processes, organizational and institutional) in the studied public sector. In addition to suggest possible promising theoretical contributions in two areas: the literature about intellectual capital and innovation in the public sector and, in practice, the identification of items that directly influence on the capacity to innovate, where the local public administration can enhance its competencies to meet in a more efficient way the social demands of the community.

The first contribution relates to the importance of the human capital as an element of the intellectual capital, considering the researches in the private sector point out as the main dimension of intellectual capital (Rodrigues et al., 2009; Bontis y Girardi, 2000). The study confirmed the importance of the element also in the public sector, as well as presenting the constructs: Training and Skills (CH1_For_Hab) and Values and Attitudes (CH2_Val_Ati) as consistent exploratory factors for future researches.

In relation to the contribution with the bibliography about capacity to innovate, three factors are presented, according to the studied literature: capacity to innovate in services and processes (Cl_Serv_Proces), organizational (Cl_Org) and institutional (Cl_Inst). Besides, through main components analysis, the constructs were intended to theoretically group useful content to study the case, with possibilities to expand and understand another typologies, such as social capacity to innovate, conceptual capacity to innovate, among others.

\footnotetext{
"Visión de Futuro" Año 18, Volumen N²5 N², Julio - Diciembre 2021 - Pág 137 - 153

URL de la Revista: http://visiondefuturo.fce.unam.edu.ar/index.php/visiondefuturo/index

URL del Documento: https://visiondefuturo.fce.unam.edu.ar/index.php/visiondefuturo/issue/view/21

ISSN 1668 - 8708 - Versión en Línea

E-mail: revistacientifica@fce.unam.edu.ar
} 
From a practical point of view, it is suggested that there are experiences in other fields is suggested to the expansion of human development in the Santiago City Council. Onah (2015, p.187) states human capital development refers to "(...) a process of training, education and other professional initiatives, in order to increasing the staff members' level of knowledge, skills, values and social assets which will lead to a higher level of satisfaction and work and, eventually, organizational performance". For this reason, though a consistent planning, there will be a greater chance of positive reflects to the human capital development, in this way, the employees tend to acquire new or improve their skills for the efficient execution of the functions for which they were hired (Ekemam y Okpara, 2020).

Despite the study has contributed by pointing out possible ways to test the influence of human capital on the capacity to innovate in the public sector, the model can be extended, and can be tested in multiple cases, including with a survey, in different places. Testing the same hypotheses in different scenarios could definitely contribute to fill the proposed theoretical gap, confirming the findings detailed here.

\section{Acknowledgments}

To the public servants of Santiago City Hall - Rio Grande do Sul, Brasil.

\section{REFERENCES}

Please refer to articles in Spanish Bibliography.

\section{BIBLIOGRAPHICAL ABSTRACT}

Please refer to articles Spanish Biographical abstract.

\footnotetext{
"Visión de Futuro" Año 18, Volumen $N^{\circ} 25$ No 2, Julio - Diciembre 2021 - Pág 137 - 153

URL de la Revista: http://visiondefuturo.fce.unam.edu.ar/index.php/visiondefuturo/index

URL del Documento: https://visiondefuturo.fce.unam.edu.ar/index.php/visiondefuturo/issue/view/21

ISSN 1668 - 8708 - Versión en Línea

E-mail: revistacientifica@fce.unam.edu.ar
} 